\title{
標高を考慮した住宅の省エネルギー基準の地域区分に関する考察 STUDY ON AREA CLASSIFICATION OF ENERGY CONSERVATION STANDARDS FOR RESIDENTIAL BUILDINGS IN CONSIDERATION OF ALTITUDE
}

\author{
窪田真 樹*, 二宮秀與**, 曽 我和 弘*** \\ Masaki KUBOTA, Hideyo NIMIYA and Kazuhiro SOGA
}

\begin{abstract}
In the energy conservation standards for residential buildings, the standard value for annual heating / cooling load is stipulated for each territory. The division of territory is determined based on the heating degree-days, which have high correlation with heating load. This paper clarifies the effect of altitude on this area classification, and examines a new area classification that reflects the altitude at an arbitrary point. The obtained results are as follows: (1) Heating / cooling degree-days have a close correlation with latitude and altitude. (2) By utilizing the relation between ambient temperature and altitude, the heating / cooling degree-days at sea level $(0 \mathrm{~m})$ without the effect of altitude can be obtained. (3) On the basis of the heating / cooling degree-day at sea level, the heating / cooling degree-days at an arbitrary point can be estimated. (4) By employing the estimated values of the heating / cooling degree-days, a new area classification corresponding to the trends in annual heating / cooling load at an arbitrary point can be performed.
\end{abstract}

Keywords : Energy conservation standards for residential buildings, Area classification, Heating/cooling degree-days, Correction of altitude 住宅の省エネルギー基淮，地域区分，暖房·冷房度日，高度補正

\section{1.はじめに}

我国では二度の石油危機を契機に「エネルギーの使用の合理化に 関する法律」が昭和 54 年に制定され、これに基づき住宅における 省エネルギー対策を進めるべく、「住宅に係るエネルギーの使用の合 理化に関する建築主の判断基準」及び「住宅に係るエネルギーの使 用の合理化に関する設計及び施工の指針」(以下、これら二つを併せ て「省エネルギー基準」1）とする。）が昭和 55 年に制定された。省 エネルギー基準では、住宅の空調熱負荷において暖房負荷が支配的 であることから、暖房負荷の低減を目的とし、熱損失係数や最小断 熱厚等の基準が定められた。

日本は北緯 $20^{\circ}$ から北緯 $46^{\circ}$ に及ぶ幅広い緯度域にある島国で、 亜熱帯から亜寒帯まで広い気候帯にあり、さらに起伏に富んだ山脈 が日本列島を縦横に走っているため、気候的差異が大きい。そこで、 省エネルギー基準では、暖房負荷の程度に応じた適切な基準值を定 めるため、同程度の気候の地域を一つにまとめる地域区分が考えら れた。昭和 55 年当初の地域区分は、日本を 5 つの地域に区分し、 各都道府県にそれぞれ 1 つの地域を割当て区分していた。暖房負荷 を中心として日本全国を統一的な指標で区分するため、地域の選択
には暖房負荷と相関が高い暖房度日:D18-18(以下、HDD18 とする。) が用いられている。また、当時の省エネルギー基準はあくまで判断 の目安としての任意基準であり、普及を図る上で簡便なものとする 行政的方針があったため、比較的大きな都道府県単位が用いられ、 各地域内のある程度の気候的差異は許容されていた。

省エネルギー基準は、その後暖冷房等の普及による消費エネルギ 一の増加に応じるため、平成 4 年及び平成 11 年にそれぞれ断熱基 準の強化や冷房負荷の低減を目的とした夏期日射取得係数の導入等 が行われた。このとき、地域区分についても見直しが行われている。 平成 4 年には冷房主体の沖縄等の南西諸島を考慮して、日本を $6 つ$ の地域に区分することとなった。さらに、平成 11 年にはそれまで の都道府県を単位とする区分から市区町村を単位とする区分に改め られた。このように地域区分の見直しでは、区分する地域の追加、 適用寸る地域の細分化を行うことで、区分内の気候的差異を小さく することを目指している。

しかし、現行の地域区分が適用単位としている市区町村内であっ ても標高に大きな差があるような場合、必ずしも気候状態が同じと は限らない。この点において現行の地域区分にはさらなる改善の余
* 鹿児島大学大学院理工学研究科 博士後期課程 · 修士 (工学)

** 鹿児島大学大学院理工学研究科 教授 ·博士 (工学)

$* * *$ 鹿児島大学大学院理工学研究科 准教授・博士 (工学)
Graduate Student, Graduate School of Science and Engineering, Kagoshima Univ., M. Eng.

Prof., Graduate School of Science and Engineering, Kagoshima Univ., Dr. Eng. Assoc. Prof., Graduate School of Science and Engineering, Kagoshima Univ., Dr. Eng. 
地がある。理想的には、建設地点ごとの気象データに基づき適用す る地域区分を決定することであるが、アメダス気象データでも観測 地点に限りがあり、任意地点の気象データを得ることは困難である。 さらに、気温等の気象要素には年毎の変動があり、長期間の観測を 行わなければ正確な気候状態を把握することはできない。そこで、 本報では現行の地域区分に用いられた 1981 年から 1995 年の 15 年 間の気象データを用い、任意地点における気候状態の表し方につい て考察する。また、住宅の空調熱負荷における冷房使用の増加を考 慮し、現行の地域区分で対象としていない泠房負荷について、地域 区分への必要性と導入方法を考察する。

日本全国の気候状態を表した気候分布の研究は、関口による気候 区分 2)等が挙げられる。建築の省エネルギーの観点から空調熱負荷 に着目した気候分布については、省エネルギー住宅システムの開発 報告書 ${ }^{3)}$ で検討がなされている。報告書では、日本全国 152 地点の 気象官署の 1951 年から 1980 年の 30 年間の月別気象統計值を利用 して M 值注 1 , 4) 算出し、目的変数を $\mathrm{M}$ 值、説明変数を緯度、標高 とした重回帰分析が行われている。この重回帰分析の結果、 $M$ 值と 緯度、標高に高い相関があることが示されており、日本全国の気候 分布には緯度、標高が大きく関わっていることが分かる。しかし、 一方で冬期の太平洋側と日本海側の天気の違いのような特有の気候 状態による緯度、標高以外の要因に起因した気候分布への影響も示 唆されている。本報では既往の研究結果 3)を踏まえ、緯度、標高の 影響に留意して、任意地点における地域区分に必要な気候状態の表 し方とそれを利用した地域区分の方法を論ずる。

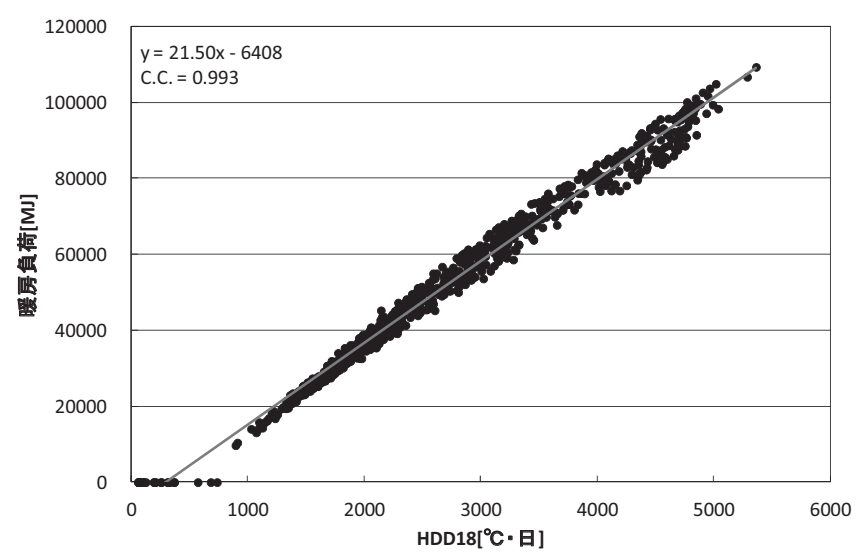

図 1 HDD18 と暖房負荷の相関

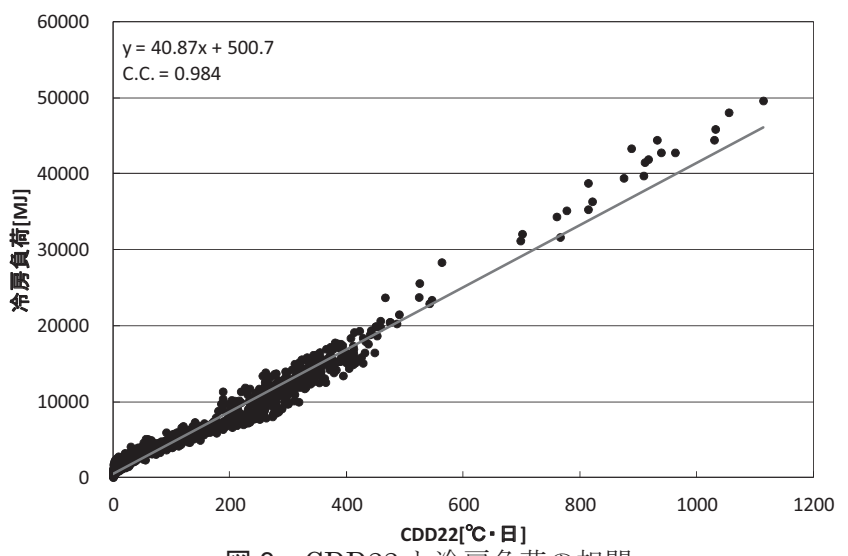

図 3 CDD22 と冷房負荷の相関

\section{2. 暖冷房負荷と気候指標の関係性}

地域区分を行うにあたって、始めに現行の地域区分同様に気候状 態を表す気候指標を定める。暖房負荷と相関が高い気候指標には、 現行の地域区分の判断材料として用いられている HDD18 の他、既 往研究 ${ }^{3)}$ により示された $\mathrm{M}$ 值を用いて算出する暖房デグリ $\mathrm{M}$ 值注 2),5) $: \mathrm{HDM}_{24-24}$ （以下、HDM24 とする。）がある。M 值は気温、水 平面全天日射量、絶対湿度の 3 気象要素の日平均值を重み付け線形 結合した単一指標である。このことから、HDM24 は暖房負荷への 日射や湿度の影響についても表していると言える。拡張アメダス気 象データ 6)（以下、EA 気象データとする。）における日本全国 842 地点の 1981 年から 1995 年を対象とした標準年気象データを用い、 それぞれの気候指標之暖房負荷を計算し、図 1 に HDD18 と暖房負 荷、図 2 に HDM24 と暖房負荷の相関関係を示す。ここで用いる暖 房負荷は、図 5 に示寸「住宅事業建築主の判断基準の住宅モデル」 7)を対象として $\mathrm{SMASH}^{8)}$ を用い計算したものである。図 1 、図 2 よ り HDD18、HDM24 ともに暖房負荷との高い相関が確認できる。 さらに、図 1 と図 2 を比較すると、暖房負荷に対する HDD18 と HDM24 の相関関係に大きな違いがないことが分かる。これより、 気温のみの気候指標で暖房負荷との関係を十分に示寸ことができる と言える。また、日射の影響は建物モデルや隣棟の有無等の敷地条 件に左右され、湿度は気温と高い相関関係にある。よって、本報で は日射、湿度の影響を含まない HDD18 を気候指標とする。

同様に泠房負荷についても図 3 に冷房度日 : D 22-22（以下、CDD22 とする。）と冷房負荷、図 4 に冷房デグリ $\mathrm{M}$ 值注 ${ }^{3), 5} \mathrm{CDM}_{24-24}$ ：(以

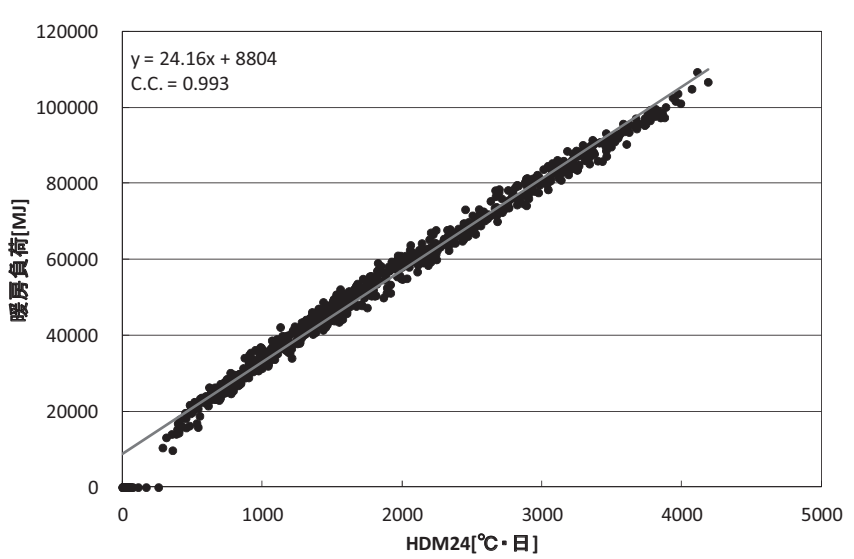

図 2 HDM24 と暖房負荷の相関

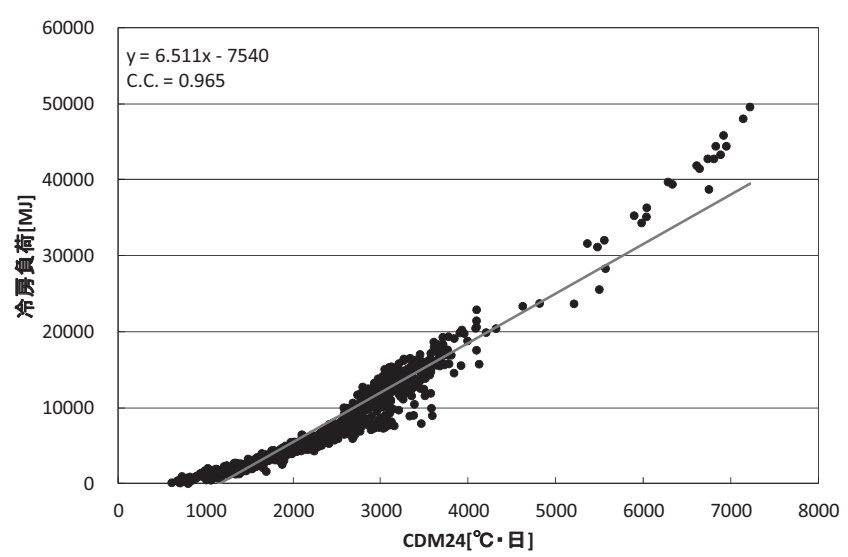

図 4 CDM24 と冷房負荷の相関 
下、CDM24 とする。）と冷房負荷の相関関係をそれぞれ示す。図よ り CDD22 が冷房負荷と高い相関関係にあることが分かるので、冷 房負荷について考慮する際は CDD22 を気候指標とする。
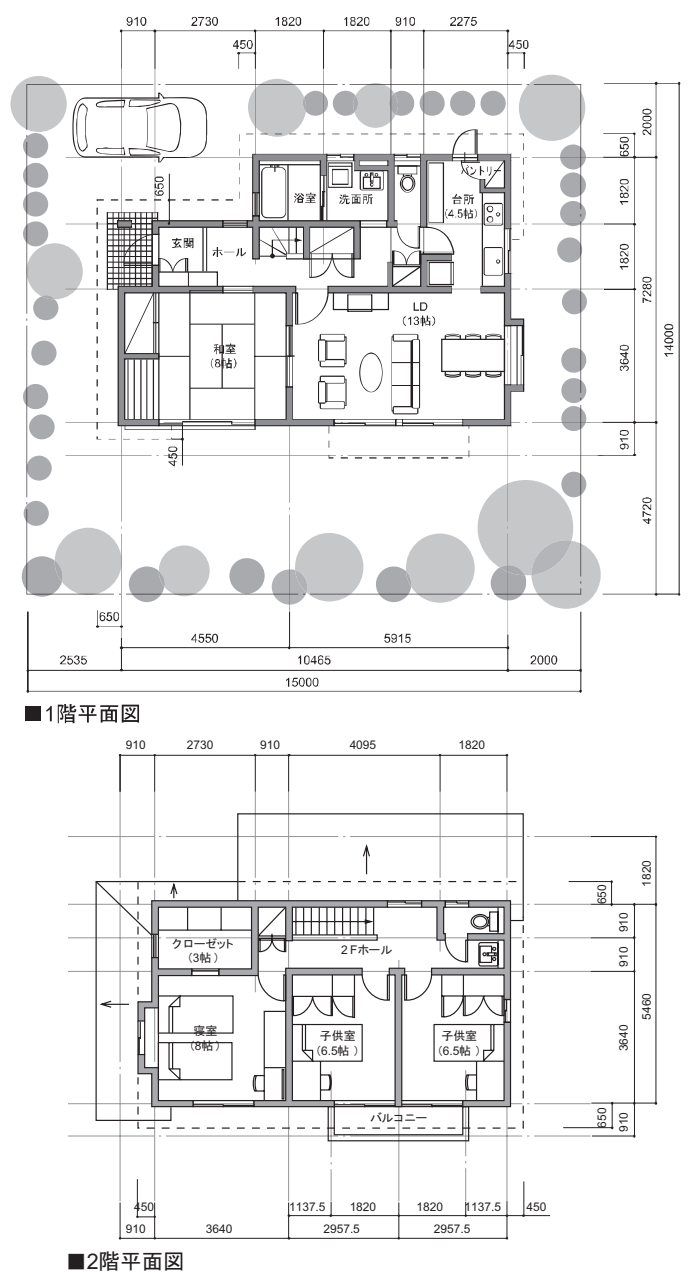

図 5 住宅事業建築主の判断基準の住宅モデル(平面図) ${ }^{7}$ )

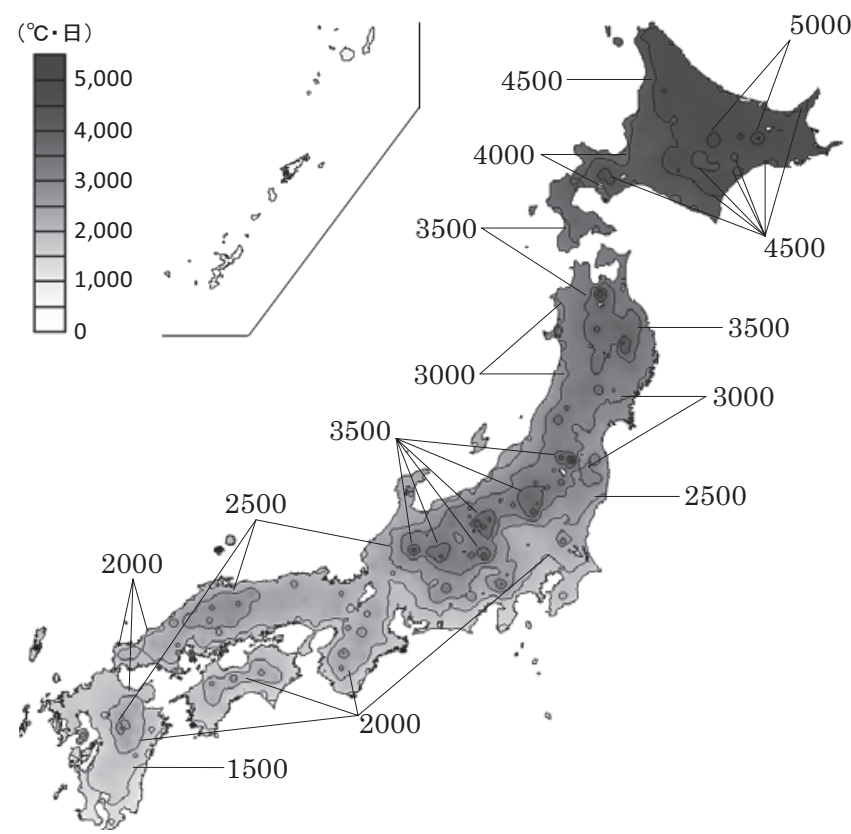

図 6 HDD18 の分布
3. HDD18に対する緯度、標高の影響と高度補正

図 6 に HDD18 の分布を示す。図 6 より高緯度になるに従って HDD18 が増加することを確認できる。さらに、図 6 では同程度の 緯度域と比較して HDD18 が大きく島状に分布している地域が見ら れた。この島状の分布が現れる場所は主に標高の高い地域で、周辺 地域との高低差の影響によって気温差が生じ、このような分布傾向 を示したものと推察される。気温減率は対流圈で $6^{\circ} \mathrm{C} / \mathrm{km}$ 程度 ${ }^{9)}$ と 知られており、標高が高くなることで気温が低下し、HDD18 が増 加したと説明できる。次に、標高以外の要因による影響について考 察するため、気温減率を用いた式(1)による海抜 $0 \mathrm{~m}$ への高度補正を 試みる。

$\mathrm{T}_{0}=\mathrm{T}+0.006 \mathrm{~h}$

$\mathrm{T}_{0}$ : 海抜 $0 \mathrm{~m}$ における気温 $\left[{ }^{\circ} \mathrm{C}\right] \mathrm{T}$ : 各地点標高での気温 $\left[{ }^{\circ} \mathrm{C}\right]$

$\mathrm{h}:$ 標高 $[\mathrm{m}]$

式(1)を用いて海抜 $0 \mathrm{~m}$ における日平均気温を算出し、海抜 $0 \mathrm{~m}$ に おける HDD18 (以下、HDD18 $0 \mathrm{~m}$ と寸る。) を求める。図 7 に HDD $180 \mathrm{~m}$ の分布を示寸。図 6 に見られた島状に存在していた分布が、図 7 で は見られない。これより、図 6 に見られた島状の分布が標高に起因 していたことが分かる。また、図 7 は HDD 18 への標高以外の要因 に起因した影響が表された分布となっているので、図に見られる高 緯度になるに従って HDD180m が増加する傾向は、HDD18 と緯度 の関係性を示していると言える。しかし、HDD $18_{0 \mathrm{~m}}$ の分布は、完 全に緯度に沿ったものではなく、海洋や地形等の影響も考えられる。

\section{4. 任意地点における地域区分}

本節ではこれまでに分かった HDD 18 及び HDD $180 \mathrm{~m}$ と緯度、標 高の関係を踏まえて、任意地点に適応した地域区分の方法を考察す る。始めに任意地点での気候状態を表す方法として HDD18 の推定 を試みる。推定した HDD18（以下、HDD18 est とする。）を用いる ことで、気象データを得ることが困難な地域についても気候状態を 判断し、それに則した適切な地域区分を可能にする。HDD18の推

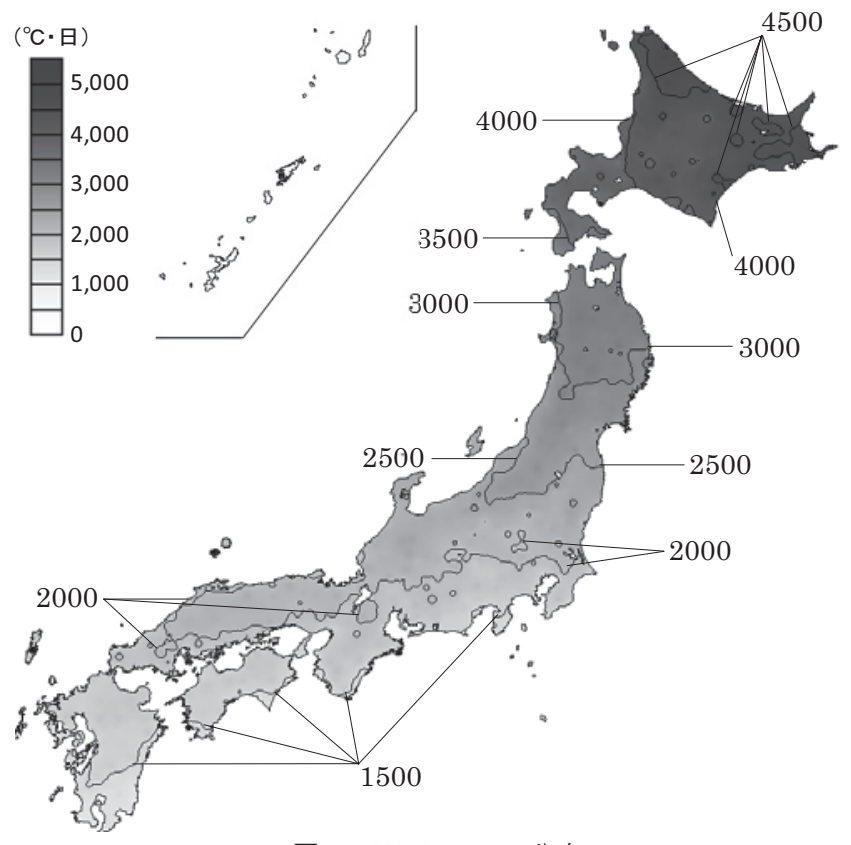

図 7 HDD $18_{0 \mathrm{~m}}$ の分布 
定方法として既往研究 ${ }^{3) を}$ 参考にし、式(2)に示す緯度、標高を用い た重回帰式による近似を試みる。図 8 に観測值より算出した HDD 18 と重回帰式による HDD $18_{\mathrm{est}}$ の相関関係を示す。図より比較的高い 相関が確認できる。しかし、近似直線の傾きや HDD 18 の $4900^{\circ} \mathrm{C}$ ・ 日付近における下方へのプロットの偏りも見られ、RMSE は $200^{\circ} \mathrm{C} \cdot$ 日を超える。この推定誤差は、既往研究 3 におおいも指摘されてい る緯度、標高以外の要因による影響である。

$\mathrm{HDD}_{1} 8_{\mathrm{est}}=252.0 \phi+1.587 \mathrm{~h}-6869$

HDD18 est : HDD18 の推定值 $\left[{ }^{\circ} \mathrm{C} \cdot\right.$ 日] $\quad \phi$ : 緯度 $\left[{ }^{\circ}\right] \mathrm{h}$ : 標高 $[\mathrm{m}]$

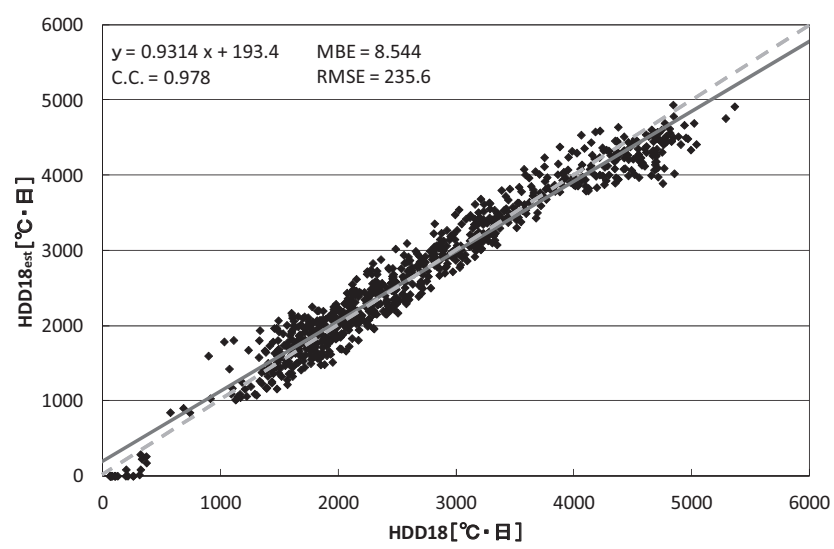

図 8 HDD18 と重回帰式による HDD18 est $_{\text {の }}$ 相関

そこで、緯度、標高以外の要因の影響を考慮するため、現行の地 域区分を参考に新たな HDD18 の推定方法を試みる。現行の地域区 分ではHDD18の気候分布に基づき、区分の最小単位を市区町村と 細分化することで、一つの地域内の気候的差異を小さくする工夫が なされている。また、前節より標高の影響が除かれた HDD $180 \mathrm{~m}$ は近隣地域間の変化、つまり気候的差異が小さいことが分かってい る。これらを踏まえて、本報では HDD18 の推定を次のイ、ロの手 順で行う。HDD18 $0 \mathrm{~m}$ を用いてまとめることで、気候的差異の小さ い地域が HDD18 を用いる場合より広くまとめられる。さらに、標 高の影響が除かれた HDD180m を基準として、後から標高による影 響を考慮することで、近隣地域間の大きな標高差から生じる気候的 差異に対応した気候状態の判断材料とすることができる。

イ. HDD $180 \mathrm{~m}$ を一定の地域範囲でまとめる。

ロ.イに対して任意地点の標高により増加する HDD18 を加える。 4-1. HDD18 ${ }_{0 \mathrm{~m}}$ の区分

HDD180m は日本全国一定ではないので、同じ気候状態の地域を まとめる必要がある。現行の地域区分で区分の適用単位を市区町村 としているのは、区分する際に用いる HDD18 の近隣地域間の差が 大きいからである。HDD $180 \mathrm{~m}$ は日本全国一定ではないものの、 HDD18 の分布と比較して近隣地域間の差が小さい。よって、 HDD $18_{0 \mathrm{~m}}$ の区分は市区町村より広い範囲とすることが可能である。 イ、ロの手順により HDD18 を推定するにあたって、基準となる HDD $180 \mathrm{~m}$ をまとめる地域範囲を広くすることは推定の簡便化を図 ることができる。しかし、一方でまとめた一つの地域内の気候的差 異が大きくなるため、推定精度の低下に注意が必要である。 HDD $180 \mathrm{~m}$ をまめる地域範囲として都道府県単位を用いた場合、 長野県のように南北に長い県で HDD $180 \mathrm{~m}$ に大きな差が見られた。
長野県はアメダス地点間の緯度に最大で約 $1.6^{\circ}$ （距離にして約 $180 \mathrm{~km}$ ）の差があり、緯度による影響が強く現れたと推察される。 よって、HDD18 $0 \mathrm{~m}$ をまとめる地域範囲としては都道府県より狭い 範囲を考える。

一つの候補として各都道府県を $2 、 3$ の地域に分類した 1 次細分 区域がある。1 次細分区域とは、気象庁が気候特性、災害特性およ び地理特性により日本全国を142 ヶ所の天気予報区に分割したもの である。図 9 に HDD $180 \mathrm{~m}$ の各アメダス地点の值を $\square 、 1$ 次細分区 域ごとの HDD $18_{0 \mathrm{~m}}$ の平均值 (以下、 $\overline{\mathrm{HDD} 18_{0 \mathrm{~m}}}$ とする。) をので示す。 $\overline{\mathrm{HDD} 18_{0 \mathrm{~m}}}$ については式(3)により算出する。図より各アメダス地点の 值と平均值のズレは小さく、平均的なズレが $110^{\circ} \mathrm{C} ・$ 日程度に収まっ ていることが確認できた。ここで、以下に示す(1)から(4)の手順によ り算出した HDD18（以下、HDD18*とする。）の分布を図 10 に示 す。図 6 と図 10 を比較して大きな違いは見られない。これより、 HDD $180 \mathrm{~m}$ をまとめる地域範囲に 1 次細分区域を用いることとする。 (1).アメダス地点の海抜 $0 \mathrm{~m}$ における日平均気温を求める。

(2). 1 次細分区域ごとに(1)の平均值を求める。

(3). (2)をアメダスの地点標高に高度補正し日平均気温を求める。

(4). (3)を用いてアメダス地点の HDD18 を求める。

$\overline{\mathrm{HDD} 8_{0 \mathrm{~m}}}=\sum_{1}^{\mathrm{p}} \sum_{1}^{\mathrm{n}}\left(18-\mathrm{T}_{0 \text { ave }}\right) / \mathrm{p}$

$\overline{\mathrm{HDD} 18_{0 \mathrm{~m}}}: 1$ 次細分区域ごとの $\mathrm{HDD} 18_{0 \mathrm{~m}}$ の平均值 $\left[{ }^{\circ} \mathrm{C} ・\right.$ 日]

$\mathrm{T}_{\text {Oave }}$ : 海抜 $0 \mathrm{~m}$ における日平均気温の 1 次細分区域ごとの平均值 $\left[{ }^{\circ} \mathrm{C}\right]$ $\mathrm{p}: 1$ 次細分区域内のアメダス地点数

$\mathrm{n}: \mathrm{T}_{\text {ave }}$ が $18^{\circ} \mathrm{C}$ 以下となる日数 [日]

4-2. HDD180m と標高を用いた HDD18 の推定

HDD18 の推定には、1 次細分区域ごとに算出した $\overline{\mathrm{HDD} 18_{0 \mathrm{~m}}}$ に対 して標高の影響を加味する必要がある。 $\overline{\mathrm{HDD} 18_{0 \mathrm{~m}}}$ に対する標高の影 響は、気温低下に伴う HDD18 の増加として現れる。そこで、 $\overline{\mathrm{HDD} 18_{0 \mathrm{~m}}}$ に標高に起因した HDD18 の増加量（以下、 $\triangle \mathrm{HDD} 18$ と する。）を加えることで任意地点における HDD18の推定を行う。標 高と $\triangle \mathrm{HDD} 18$ の関係については以下に示寸二つの特徴が見られた ので、この点に留意し推定式を作成する。

1. 高緯度地域になるに従って $\triangle \mathrm{HDD} 18$ は大きくなる。

2. 高所になるに従って単位標高あたりの $\Delta \mathrm{HDD} 18$ は大きくなる。

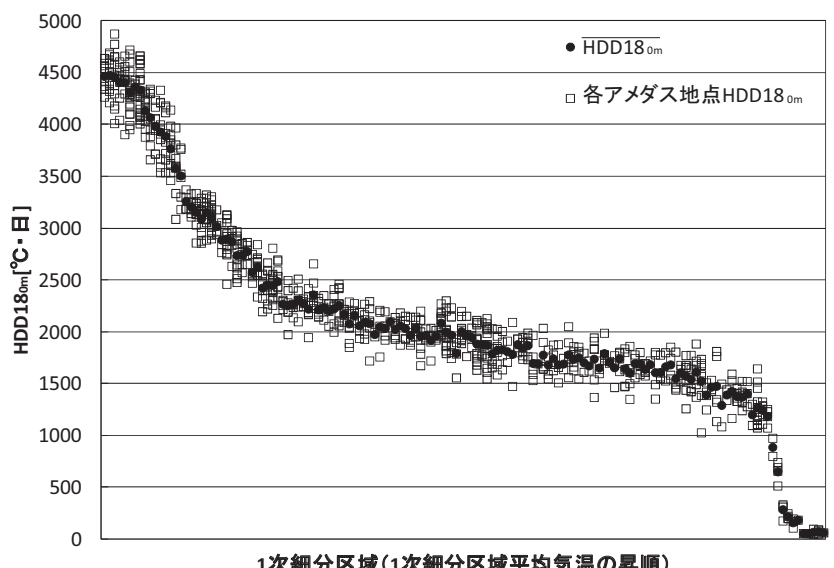

図 9 各アメダス地点における HDD $18_{0 \mathrm{~m}}$ と 1 次細分区域 ごとの $\mathrm{HDD} 18_{0 \mathrm{~m}}$ の平均值 $\overline{\mathrm{HDD} 18_{0 \mathrm{~m}}}$ 


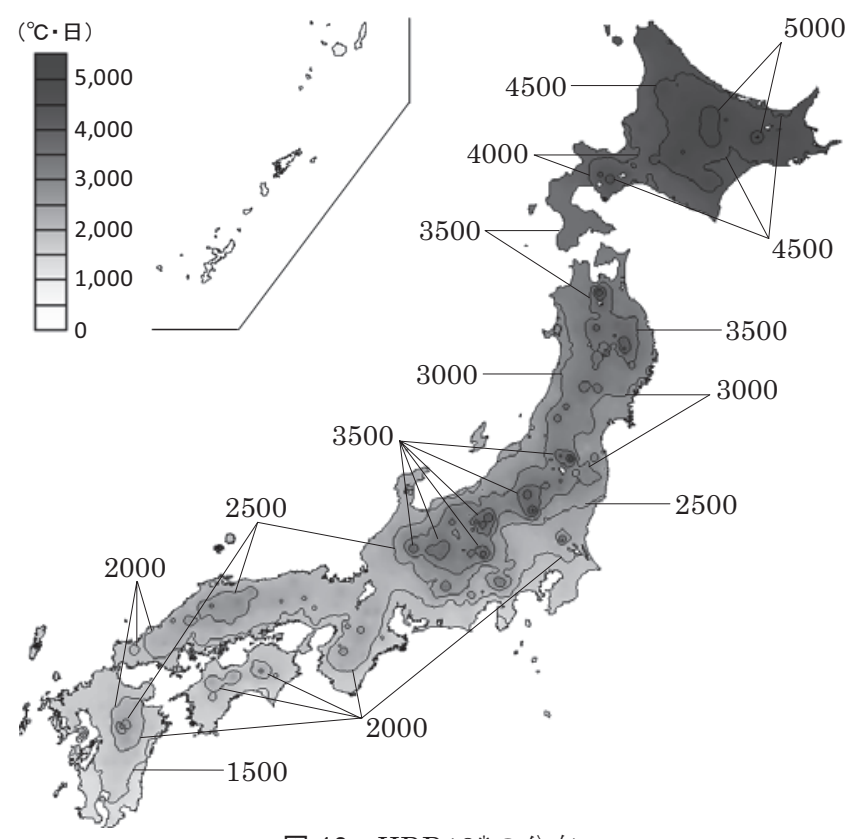

図 $10 \mathrm{HDD} 18 *$ の分布

二つの特徴については、図 11 に例示する岩手県内陸と鹿児島県 薩摩地方の標高と $\triangle \mathrm{HDD} 18$ の関係から確認できる。図に示寸 2 次 の近似曲線は、 $0 \mathrm{~m}$ から $1000 \mathrm{~m}$ まで $1 \mathrm{~m}$ 間隔で算出した $\Delta \mathrm{HDD} 18$ に対するものである。その際必要となる各標高における気温につい ては式(4)を用いて算出した。また、図にはこの 2 次の近似曲線の確 認のため、観測值より算出した HDD18 と HDD $180 \mathrm{~m}$ の差から求め た $\triangle \mathrm{HDD} 18$ を併せてプロットしている。プロットより 2 次の近似 曲線の妥当性がうかがえる。

$\mathrm{T}_{\mathrm{h}}=\mathrm{T}_{0}-0.006 \mathrm{~h}$

$\mathrm{T}_{\mathrm{h}}$ : 標高 $\mathrm{h} \mathrm{m}$ における気温 $\left[{ }^{\circ} \mathrm{C}\right] \quad \mathrm{T}_{0}$ : 海抜 $0 \mathrm{~m}$ における気温 $\left[{ }^{\circ} \mathrm{C}\right]$ $\mathrm{h}:$ 標高 $[\mathrm{m}]$

図 11 からの特徴により鹿児島県と比較して高緯度地域の岩手県 は $\Delta \mathrm{HDD} 18$ が大きいことが分かる。標高が $500 \mathrm{~m}$ の場合、鹿児島 県の $\Delta \mathrm{HDD} 18$ が約 $600^{\circ} \mathrm{C} \cdot$ 日であるのに対し、岩手県では約 $800^{\circ} \mathrm{C} \cdot$ 日である。さらに、同じ岩手県でも低所の $200 \mathrm{~m}$ から $300 \mathrm{~m}$ までの $100 \mathrm{~m}$ 間の $\triangle \mathrm{HDD} 18$ は約 $160^{\circ} \mathrm{C} ・$ 日 $/ 100 \mathrm{~m}$ であるのに対し、高所の $500 \mathrm{~m}$ から $600 \mathrm{~m}$ までの $100 \mathrm{~m}$ 間では約 $180^{\circ} \mathrm{C} \cdot$ 日 $/ 100 \mathrm{~m}$ と大きいこ とが分かる。このため、1 次細分区域ごとに推定式を作成し、 HDD18 2 次の近似曲線で求めることとした。HDD18 の推定は、
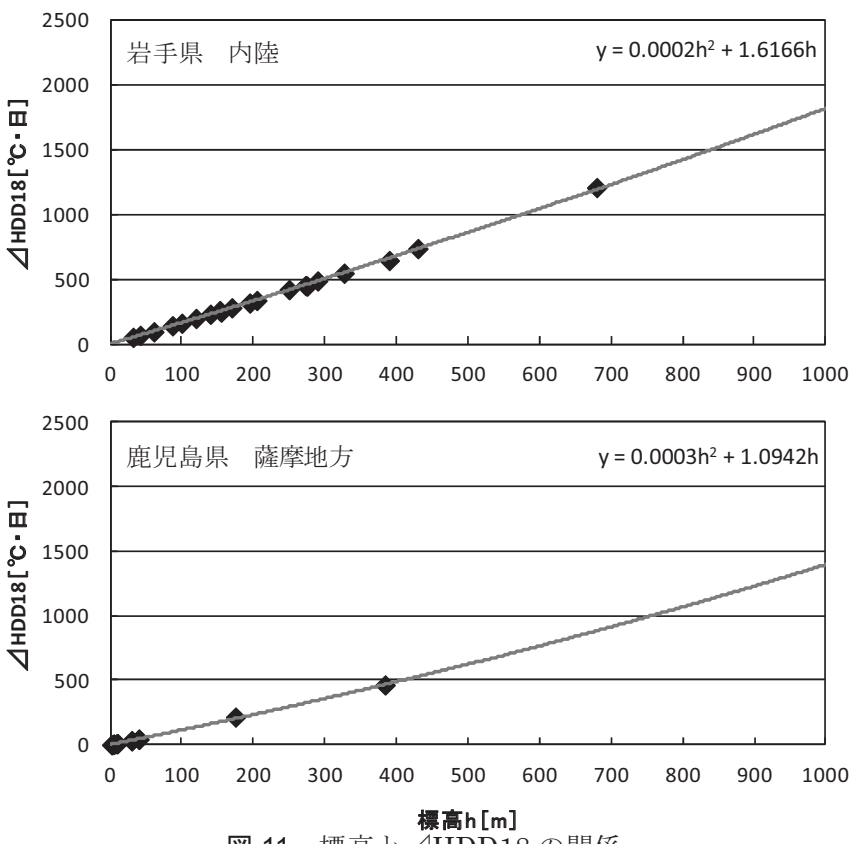

図 11 標高と $\triangle \mathrm{HDD} 18$ の関係

$\overline{\mathrm{HDD} 18_{0 \mathrm{~m}}}$ に $\triangle \mathrm{HDD} 18$ を加える式(5)で行う。推定に必要な $\overline{\mathrm{HDD} 18_{0 \mathrm{~m}}}$ 、 係数 $\mathrm{a} 、 \mathrm{~b}$ は 1 次細分区域ごとに整理する。一例を表 1 に示す。

HDD18 $8_{\text {est }}=\overline{\mathrm{HDD}_{0 \mathrm{~m}}}+\mathrm{a} \mathrm{h} \mathrm{h}^{2}+\mathrm{bh}$

HDD18 est : HDD18 の推定值 $\left[{ }^{\circ} \mathrm{C} \cdot\right.$ 日] $\mathrm{a}$ : 係数 $\left[{ }^{\circ} \mathrm{C} \cdot\right.$ 日 $\left./ \mathrm{m}^{2}\right] \mathrm{b}$ : 係数 $\left[{ }^{\circ} \mathrm{C} \cdot\right.$ 日 $\left./ \mathrm{m}\right]$ $\overline{\mathrm{HDD} 18_{0 \mathrm{~m}}}: 1$ 次細分区域ごとの $\mathrm{HDD} 18_{0 \mathrm{~m}}$ の平均值 $\left[{ }^{\circ} \mathrm{C} \cdot\right.$ 日] $\mathrm{h}:$ 標高 $[\mathrm{m}]$

4-3. HDD18 est $_{\text {による地域区分 }}$

1 次細分区域ごとに HDD18 の推定式を定めたので、任意地点に おいて 1 次細分区域と標高が得られれば HDD18 の推定は可能であ る。観測值による HDD18 と式(5)により推定した HDD18 est $_{\text {の }}$ 相関 関係を図 12 に示す。図 8 と比較してRMSEが大きく減少しており、 重回帰分析による推定より精度が高いことが分かる。このときの RMSE は観測值によるHDD18 の平均值の約 5.9\%であり、十分な 推定精度が確保されている。

地域区分する際には基準となる HDD18 est $の$ 分割範囲を定めなけ ればならない。本報では現行の地域区分等を参考に HDD $18_{\mathrm{est}}$ の分 割を $500^{\circ} \mathrm{C} \cdot$ 日間隔で行う。この分割間隔を基準值とし、そのときの 標高を表 1 右側部分「HDD18 est が下記基準值となるときの標高」 に示す。式(5)により HDD18 est を計算しなくても、1 次細分区域と 標高が分かれば表 1 より地域区分は可能である。

表 11 次細分区域別 $\overline{\mathrm{HDD} 18_{0 \mathrm{~m}}} 、 \mathrm{a} 、 \mathrm{~b}$ と HDD18 の各基準值に必要な標高の一例

\begin{tabular}{|c|c|c|c|c|c|c|c|c|c|c|c|c|c|c|c|c|}
\hline \multirow{2}{*}{ 都道府県名 } & \multirow[b]{2}{*}{ 1次細分区域名 } & \multirow[b]{2}{*}{ 地点数 } & \multirow[b]{2}{*}{ HDD18om } & \multirow[b]{2}{*}{ a } & \multirow[b]{2}{*}{ b } & \multicolumn{11}{|c|}{ HDD18が下記基準值となるときの標高h(m) } \\
\hline & & & & & & 500 & 1000 & 1500 & 2000 & 2500 & 3000 & 3500 & 4000 & 4500 & 5000 & 5500 \\
\hline 北海道 & 石狩地方 & 9 & 3874 & 0.0002 & 1.8289 & & & & & & & & 69 & 331 & 580 & 817 \\
\hline 岩手県 & 内陸 & 20 & 3078 & 0.0002 & 1.6166 & & & & & & & 253 & 535 & 801 & 1052 & 1292 \\
\hline 東京都 & 東京地方 & 7 & 1805 & 0.0003 & 1.3107 & & & & 145 & 479 & 775 & 1045 & 1293 & 1525 & 1743 & 1950 \\
\hline 神奈川県 & 西部 & 1 & 1693 & 0.0003 & 1.3128 & & & & 223 & 547 & 836 & 1100 & 1345 & 1573 & 1789 & 1993 \\
\hline 富山県 & 東部 & 4 & 2219 & 0.0003 & 1.3765 & & & & & 196 & 511 & 794 & 1053 & 1293 & 1518 & 1731 \\
\hline 大阪府 & 大阪府 & 7 & 1763 & 0.0002 & 1.2725 & & & & 182 & 535 & 857 & 1156 & 1435 & 1698 & 1948 & 2186 \\
\hline 高知県 & 中部 & 5 & 1629 & 0.0003 & 1.2790 & & & & 273 & 598 & 888 & 1152 & 1397 & 1626 & 1741 & 2046 \\
\hline 福岡県 & 福岡地方 & 4 & 1637 & 0.0003 & 1.2544 & & & & 273 & 602 & 895 & 1163 & 1409 & 1640 & 1857 & 2063 \\
\hline 鹿児島県 & 薩摩地方 & 12 & 1252 & 0.0003 & 1.0942 & & & 215 & 589 & 913 & 1202 & 1466 & 1710 & 1939 & 2154 & 2359 \\
\hline 沖縄県 & 本島北部 & 4 & 194 & 0.0004 & 0.5628 & 420 & 881 & 1236 & 1535 & 1799 & 2038 & 2257 & 2461 & 2653 & 2834 & 3007 \\
\hline
\end{tabular}

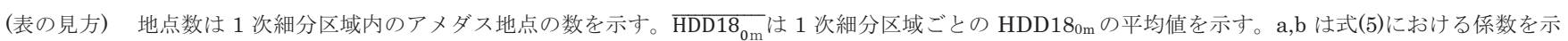
す。HDD18 が下記基準值となるときの標高 $\mathrm{h}(\mathrm{m})$ を用いると、例えば北海道石狩地方において、標高 $69 \mathrm{~m}$ 以上 $331 \mathrm{~m}$ 未満の地域は HDD $18_{\mathrm{est}}$ が $4000^{\circ} \mathrm{C} \cdot$ 日から $4500^{\circ} \mathrm{C} ・$ 日の範囲の地域と区分することができる。 


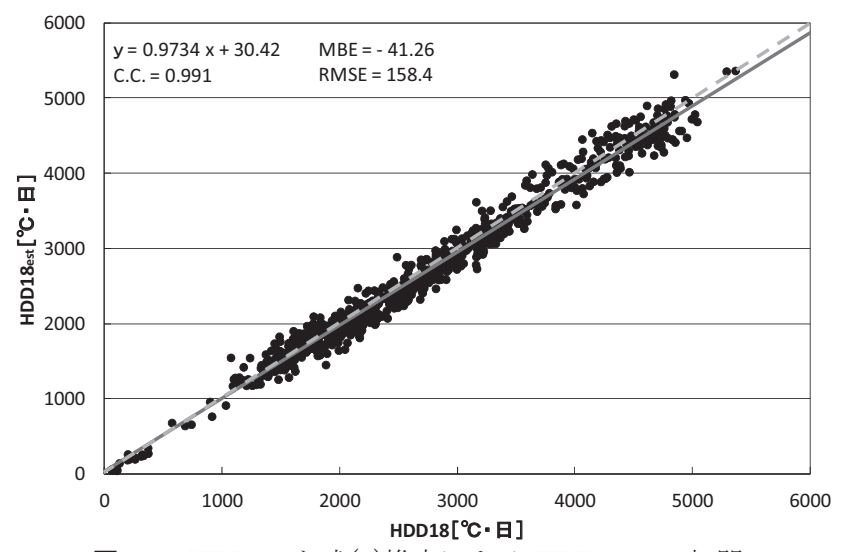

図 12 HDD18 と式(5)推定による HDD18 est $の$ 相関

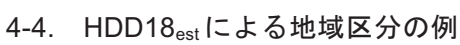

図 13 に奈良県生駒市を対象とした HDD18 est による地域区分の例 を示す。図左が Google Earth ${ }^{100}$ によ航空写真、図右が緯度経度方 向約 $1 \mathrm{~km}$ の格子状で表した模式図である。図中の A、B は表 2 に 対応する。生駒市は、標高約 $600 \mathrm{~m}$ の山間部に位置するアメダス地 点の気象データに基づいて現行の地域区分が行われており、すべて $\mathrm{A}$ に区分される。しかし、都市部は標高約 $100 \mathrm{~m}$ の平野部に位置し、 山間部との標高差が約 $500 \mathrm{~m}$ と大きく、気候的差異も大きいことが 考えられる。そこで、標高を考慮するため各格子の面平均標高を用 い、式(5)で HDD18 est を計算し区分した。結果、平野部である都市 部は新たに $\mathrm{B}$ に区分され、 $\mathrm{A} 、 \mathrm{~B}$ の 2 つの分となった。これより、 HDD18 est による地域区分は、現行の地域区分で対応できない標高差 に起因した気候的差異を考慮できることが分かる。
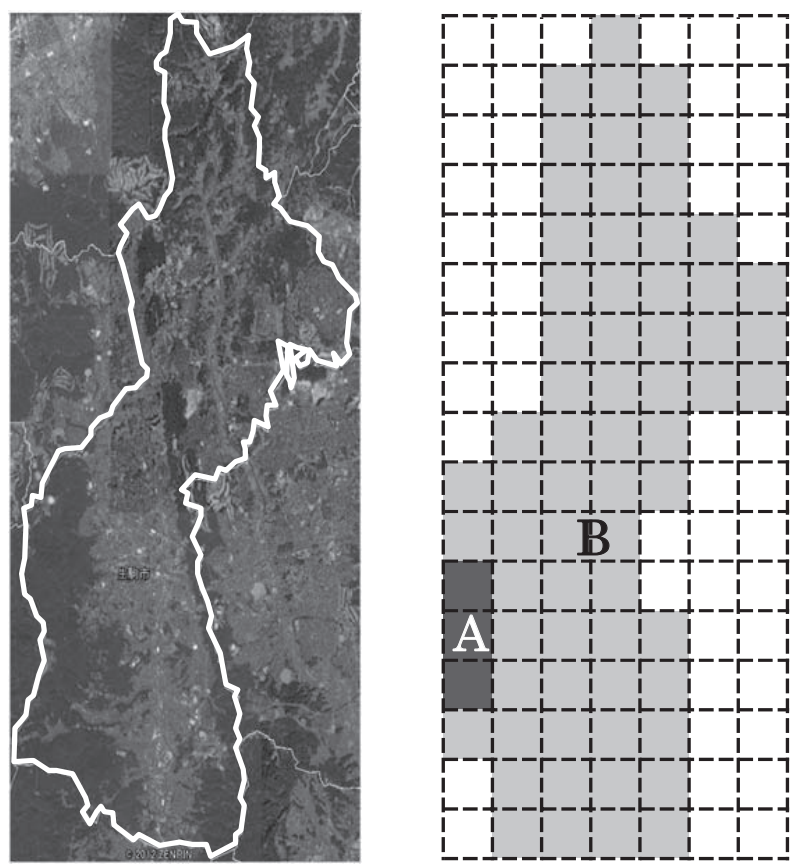

図 13 生駒市を対象とした地域区分例

表 2 生駒市の地域区分

\begin{tabular}{|c|cr|rrr|}
\hline HDD18 [ ${ }^{\circ} \mathrm{C} \cdot$ 日] & $2000 \sim 2500$ & 2500 & $\sim$ & 3000 \\
\hline 該当する地域 & B (標高406m以下) & \multicolumn{3}{|c|}{ A } \\
\hline
\end{tabular}

5. 冷房負荷を考慮した地域区分

前節までは現行の地域区分で対象としている暖房負荷に関する新 たな地域区分について考察した。住宅の空調熱負荷においては暖房 負荷が支配的であるとはいえ、沖縄等の南西諸島あるいは温暖な地 域での泠房負荷は無視することができない。このため、省エネルギ 一を目的とした地域区分にあっては泠房負荷についても考慮する必 要がある。そこで、本節では地域区分においてこれまで対象とされ ていない泠房負荷を考慮した地域区分を考察する。

HDD18 同様に海抜 $0 \mathrm{~m}$ における CDD22（以下、CDD220m とす る。）を算出し、図 14 に CDD $220 \mathrm{~m}$ の分布を示す。図より低緯度地 域になるに従って緩やかに CDD $220 \mathrm{~m}$ が増加していることが分かる。 また、分布に対する緯度、標高以外の要因による影響もうかがえる。 これより、CDD220m も HDD $180 \mathrm{~m}$ 同様に同じ気候状態の地域をまと める必要がある。CDD $220 \mathrm{~m}$ をまとめる地域範囲についても 1 次細分 区域とする。ここで、 1 次細分区域ごとに求める $\mathrm{CDD} 22 \mathrm{~m}$ の平均值 を $\overline{\mathrm{CDD} 22_{0 \mathrm{~m}}}$ とする。

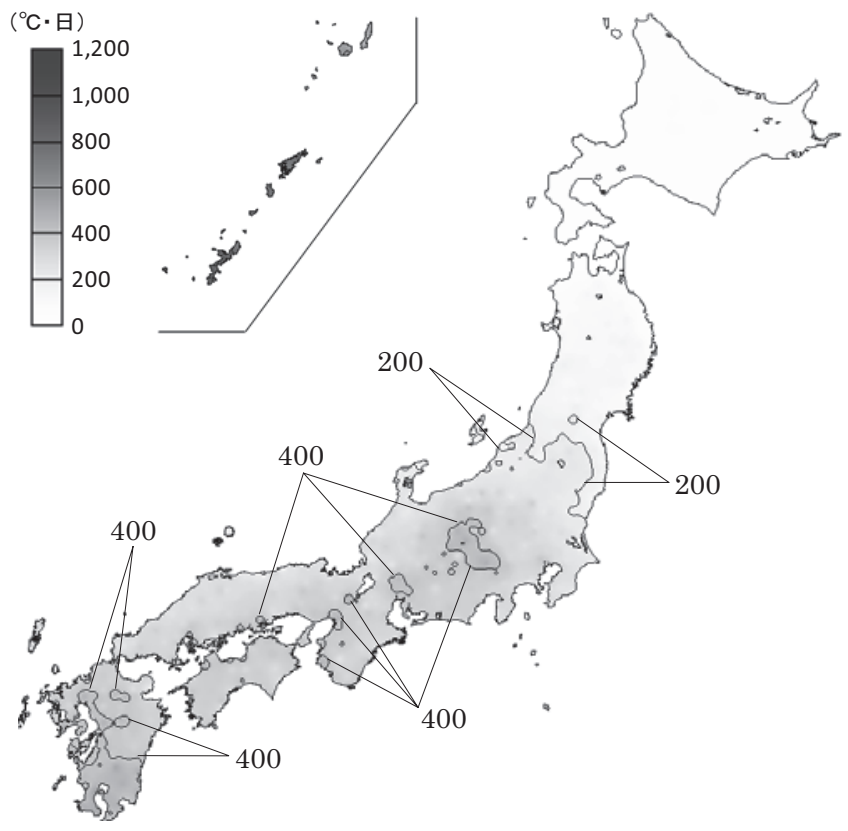

図 $14 \mathrm{CDD} 22_{0 \mathrm{~m}}$ の分布

CDD22 の推定には、 1 次細分区域ごとに算出した $\overline{\operatorname{CDD} 22_{0 \mathrm{~m}}}$ に対し て標高の影響を加味する必要がある。 $\overline{\mathrm{CDD} 22_{0 \mathrm{~m}}}$ に対する標高の影響 は、 $\overline{\mathrm{HDD} 18_{0 \mathrm{~m}}}$ に対するものとは反対で CDD22 の減少として現れる。 そこで、 $\overline{\mathrm{CDD}_{2} 2_{0 \mathrm{~m}}}$ から標高に起因した CDD22 の減少量（以下、 $\triangle$ CDD22 とする。）を差し引くことで任意地点における CDD22 の推 定を行う。標高と $\triangle \mathrm{CDD} 22$ の関係についても以下に示寸二つの特 徵が見られたので、この点に留意し推定式を作成する。

1. 高緯度地域になるに従って $\triangle \mathrm{CDD} 22$ は小さくなる。

2. 高所になるに従って単位標高あたりの $\Delta \mathrm{CDD} 22$ は小さくなる。 二つの特徵については、図 15 に例示寸る岩手県内陸と鹿児島県 薩摩地方の二つの 1 次細分区域における標高と $\triangle \mathrm{CDD} 22$ の関係か ら確認できる。図に示寸 2 次の近似曲線は、0m から $1000 \mathrm{~m}$ まで $1 \mathrm{~m}$ 間隔で算出した $\triangle \mathrm{CDD} 22$ に対するものである。その際必要とな る各標高における気温については式(4)を用いて算出した。また、図 


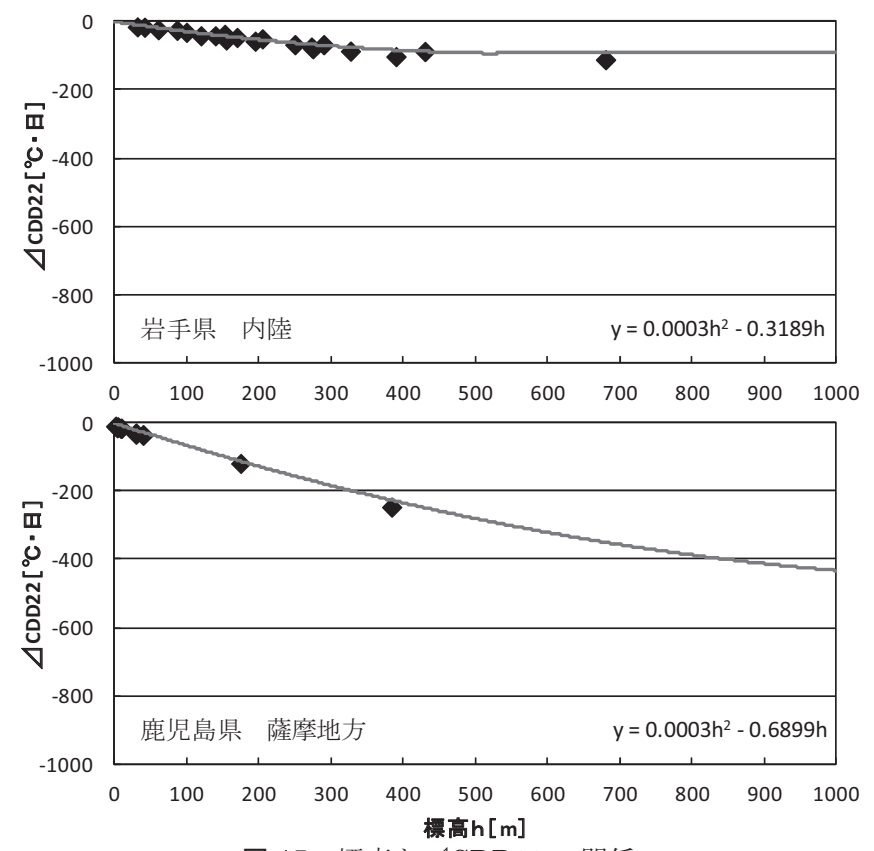

図 15 標高と $\triangle \mathrm{CDD} 22$ の関係

にはこの 2 次の近似曲線の確認のため、観測值より算出した CDD2 2 と CDD $220 \mathrm{~m}$ の差から求めた $\triangle \mathrm{CDD} 22$ を併せてプロットしている。 図 15 から鹿児島県と比較して高緯度地域の岩手県は $\triangle \mathrm{CDD} 22$ が 小さいことが分かる。標高が $500 \mathrm{~m}$ の場合、岩手県の $\Delta \mathrm{CDD} 22$ は 鹿児島より約 $190^{\circ} \mathrm{C} \cdot$ 日小さい。さらに、同じ鹿児島県でも低所の $200 \mathrm{~m}$ から $300 \mathrm{~m}$ までの $100 \mathrm{~m}$ 間の $\triangle \mathrm{HDD} 18$ は約 $54^{\circ} \mathrm{C} \cdot$ 日 $/ 100 \mathrm{~m}$ で あるのに対し、高所の $500 \mathrm{~m}$ から $600 \mathrm{~m}$ までの $100 \mathrm{~m}$ 間では約 $36^{\circ} \mathrm{C}$. 日/100m と小さいことが分かる。このため、CDD22 の推定につい ても、1 次細分区域ごとに推定式を作成し、 $\triangle \mathrm{CDD} 22$ を 2 次の近似 曲線で求めることとした。CDD22 の推定は、 $\overline{\mathrm{CDD} 22_{0 \mathrm{~m}}} に \Delta \mathrm{CDD} 22$ を加える式(6)で行う。式(6)は標高が高くなることで CDD22 が減少 することを表した推定式であり、標高が高くなると CDD22 est が負 の値となる場合がある。CDD22 $2_{\text {est }}$ が負の值となる場合については、 $\mathrm{CDD} 22_{\mathrm{est}}$ を $0^{\circ} \mathrm{C} ・$ 日として扱う。

CDD22 est $=\overline{\mathrm{CDD}_{20 \mathrm{~m}}}+\mathrm{c} \mathrm{h}^{2}+\mathrm{d} \mathrm{h}$

$\mathrm{CDD}_{2} 2_{\text {est }}$ : CDD22 の推定值 $\left[{ }^{\circ} \mathrm{C} \cdot\right.$ 日]

ただし、CDD22 est が負の值となる場合には 0 として扱う。 $\overline{\mathrm{CDD} 22_{0 \mathrm{~m}}}: 1$ 次細分区域ごとの $\mathrm{CDD} 22_{0 \mathrm{~m}}$ の平均值 $\left[{ }^{\circ} \mathrm{C} ・\right.$ 日]

$\mathrm{c}:$ 係数 $\left[{ }^{\circ} \mathrm{C} \cdot\right.$ 日 $\left./ \mathrm{m}^{2}\right] \mathrm{d}:$ 係数 $\left[{ }^{\circ} \mathrm{C} \cdot\right.$ 日 $\left./ \mathrm{m}\right] \mathrm{h}:$ 標高 $[\mathrm{m}]$

前節同様に式(6)で算出した CDD22 est みを考慮した地域区分も可能である。また、地域区分する際には CDD22 est の基準となる分割範囲を定める必要がある。ここでは、暖 房負荷と泠房負荷を同等に扱えるように、HDD $18_{\mathrm{est}}$ の $500^{\circ} \mathrm{C}$ ・日を 基準とし、このときの負荷範囲が同程度となるよう定める。図 1 か ら HDD 18 の $500^{\circ} \mathrm{C}$ ・日に対応する暖房負荷は約 $10000 \mathrm{MJ}$ であるこ とが分かる。さらに、図 3 からは冷房負荷の約 $10000 \mathrm{MJ}$ に対応す る $\mathrm{CDD} 22$ が $250^{\circ} \mathrm{C}$ ・日であることが分かるので、CDD22 $\mathrm{est}_{\text {の }}$ の分割 は $250^{\circ} \mathrm{C} ・$ 日間隔で行う。

\section{HDD18 est $_{\text {C CDD22 }}$ 吕 による地域区分}

HDD $18_{\mathrm{est}}$ と CDD22 $2_{\mathrm{est}}$ を用いたそれぞれでの地域区分を前節まで に検討した。本節ではこれら二つの推定值の組合せによる地域区分 について述べる。前節までに示した HDD $18_{\mathrm{est}}$ と $\mathrm{CDD} 22_{\mathrm{est}}$ の分割範

表 3 HDD18 と CDD22 によるアメダス地点数の分布

\begin{tabular}{|c|c|c|c|c|c|c|c|c|c|c|c|c|c|c|c|}
\hline $\begin{array}{l}\mathrm{CDD} 22 \\
\left.{ }^{\circ} \mathrm{C} \cdot \mathrm{日}\right]\end{array}$ & & $\begin{array}{l}\mathrm{HDD18} \\
{\left[\begin{array}{l}\left.{ }^{\circ} \mathrm{C} \cdot 日\right] \\
\end{array}\right]}\end{array}$ & 0 & $\sim 500$ & $500 \sim 1000$ & $1000 \sim 1500$ & $1500 \sim 2000$ & $2000 \sim 2500$ & $2500 \sim 3000$ & $3000 \sim 3500$ & $3500 \sim 4000$ & $4000 \sim 4500$ & $4500 \sim 5000$ & $5000 \sim 5500$ & 計 \\
\hline 0 & $\sim$ & 250 & & 0 & 0 & 2 & 25 & 113 & 105 & 108 & 59 & 67 & 70 & 4 & 553 \\
\hline 250 & $\sim$ & 500 & & 1 & 3 & 55 & 151 & 54 & 0 & 0 & 0 & 0 & 0 & 0 & 264 \\
\hline 500 & $\sim$ & 750 & & 4 & 2 & 1 & 0 & 0 & 0 & 0 & 0 & 0 & 0 & 0 & 7 \\
\hline 750 & $\sim$ & 1000 & & 14 & 0 & 0 & 0 & 0 & 0 & 0 & 0 & 0 & 0 & 0 & 14 \\
\hline 1000 & $\sim$ & 1250 & & 4 & 0 & 0 & 0 & 0 & 0 & 0 & 0 & 0 & 0 & 0 & 4 \\
\hline & 計 & & & 23 & 5 & 58 & 176 & 167 & 105 & 108 & 59 & 67 & 70 & 4 & 842 \\
\hline
\end{tabular}

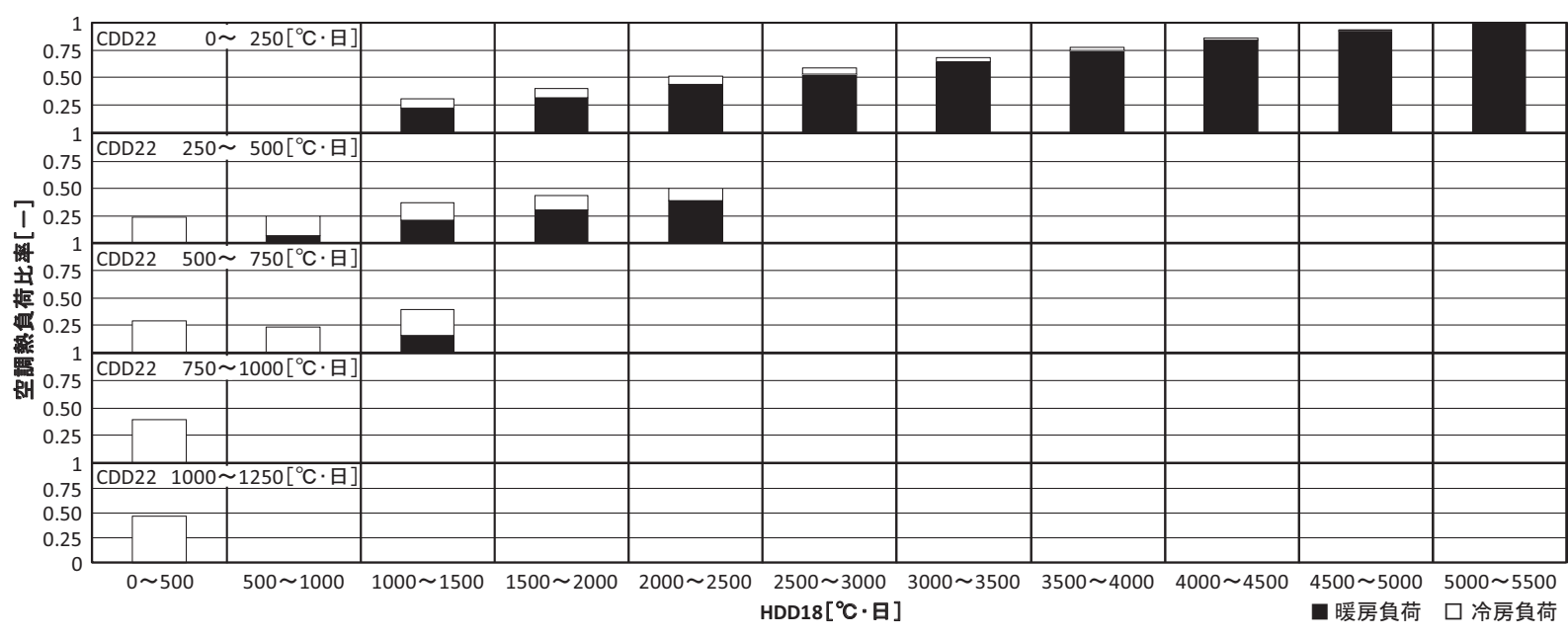

図 16 HDD18 と CDD22 による空調熱負荷比率の区分 
囲を用い、アメダス地点数の分布を表 3 に示す。表 3 より暖房負荷 を対象とした HDD18では同じ地域に区分されていても、冷房負荷 を対象とした CDD22 を組合せることで複数に区分される場合があ ることが分かる。

ここで、表 3 に示寸各区分に属するアメダス地点の年間の暖房負 荷、冷房負荷を平均し、その合計を各区分の空調熱負荷の平均值と して $100000 \mathrm{MJ}$ を 1 とした比率で図 16 に示す。暖房負荷、冷房負 荷は、「住宅事業建築主の判断基準の住宅モデル」7)を対象として $\mathrm{SMASH}^{8)}$ 用い計算したものである。図より横に見ると暖房負荷の 比率が、縦に見ると冷房負荷の比率がそれぞれ区分されていること が分かる。また、これまで暖房負荷のみを対象としたことで同じ区 分とされていた地域に関して、暖房負荷と泠房負荷の比率にいくつ かの組合せがあることが確認できる。これより、任意地点の空調熱 負荷の傾向に対して適切な省エネルギー対策を講じるためには、暖 房負荷と冷房負荷を考虑した HDD18 est と CDD22 $2_{\mathrm{est}}$ による地域区分 を行うことが望ましいと言える。

\section{7. まとめ}

本報では地域区分に関して以下の知見を得た。

（1）HDD18、CDD22 はそれぞれ暖房負荷、冷房負荷と高い相関が あり、地域区分に用いる気候指標として適している。

（2）HDD18、CDD22 は緯度、標高と密接な関係がある。

（3）海抜 $0 \mathrm{~m}$ に高度補正した場合、HDD $180 \mathrm{~m} 、 \mathrm{CDD} 22_{0 \mathrm{~m}}$ は標高に よる影響が除かれ、近隣地域間の差が小さいことが分かった。

（4） 1 次細分区域ごとに求めた $\overline{\mathrm{HDD} 18_{0 \mathrm{~m}}}$ に $\Delta \mathrm{HDD} 18$ を加える方法 で HDD18 $8_{\mathrm{est}}$ を推定する方法を提案した。任意地点において 1 次細分区域と標高が既知であれば HDD $18_{\text {est }}$ が算出でき、地域区 分できる。

（5）1次細分区域ごとに求めた $\overline{\mathrm{CDD} 22_{0 \mathrm{~m}}}$ から $\triangle \mathrm{CDD} 22$ を差し引く方 法で CDD22 est を推定する方法を提案した。任意地点において 1 次細分区域と標高が既知であれば CDD22 est が算出でき、地域区 分できる。

（6）現行の地域区分で同じ地域に区分されている場所であっても、 暖冷房負荷の比率が異なる可能性がある。暖冷房負荷の傾向に 応じた省エネルギー対策を講じるためには暖房負荷と冷房負荷 を考慮した地域区分を行うことが望ましい。

\section{謝辞}

研究の遂行にあたり北方建築総合研究所の鈴木大隆博士、東京大 学の坂本雄三博士、株式会社 Environmental Planning \& Brain の 伊藤一哉氏、株式会社砂川建築環境研究所の砂川雅彦氏、鹿児島工 業高等専門学校の赤坂裕博士には多大なご助言や資料のご提供をい ただきました。ここに記して深甚なる謝意を表します。
HDD18：暖房度日 $\left(\mathrm{D}_{18 \cdot 18}\right)\left[{ }^{\circ} \mathrm{C} \cdot\right.$ 日]

$\mathrm{HDM} 24$ : 暖房デグリ $\mathrm{M}$ 值 $\left(\mathrm{HDM}_{24-24}\right)\left[{ }^{\circ} \mathrm{C} \cdot\right.$ 日 $]$

CDD22 : 冷房度日 $\left(\mathrm{D}_{22-22}\right)\left[{ }^{\circ} \mathrm{C} \cdot\right.$ 日 $]$

$\mathrm{CDM} 24$ : 冷房デグリ $\mathrm{M}$ 值 $\left(\mathrm{CDM}_{24-24}\right)\left[{ }^{\circ} \mathrm{C} \cdot\right.$ 日 $]$

HDD $180 \mathrm{~m}$ ：海抜 $0 \mathrm{~m}$ における HDD18 $\left[{ }^{\circ} \mathrm{C} \cdot\right.$ 日]

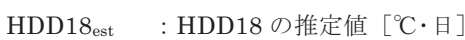

$\overline{\mathrm{HDD} 18_{0 \mathrm{~m}}}: 1$ 次細分区域ごとの $\mathrm{HDD} 18_{0 \mathrm{~m}}$ の平均值 $\left[{ }^{\circ} \mathrm{C} \cdot\right.$ 日 $]$

$\triangle \mathrm{HDD} 18$ : HDD18 の増加量 $\left[{ }^{\circ} \mathrm{C} \cdot\right.$ 日 $]$

$\mathrm{CDD} 22_{0 \mathrm{~m}} \quad$ : 海抜 $0 \mathrm{~m}$ における $\mathrm{CDD} 22\left[{ }^{\circ} \mathrm{C} \cdot\right.$ 日]

$\overline{\mathrm{CDD} 22} 2_{0 \mathrm{~m}}: 1$ 次細分区域ごとの $\mathrm{CDD} 22_{0 \mathrm{~m}}$ の平均值 $\left[{ }^{\circ} \mathrm{C} \cdot\right.$ 日 $]$

$\triangle \mathrm{CDD} 22 ： \mathrm{CDD} 22$ の減少量 $\left[{ }^{\circ} \mathrm{C} \cdot\right.$ 日]

注

注 1) $\mathrm{M}$ 值とは気温、水平面全天日射量、絶対湿度の 3 気象要素の日平均值 を重多付けして線形結合した単一指標であり、熱負荷相当外気温とも 呼ばれる。M 值は以下に示寸式によって計算できる。

$\mathrm{M}=\mathrm{T}+\mathrm{H} \cdot \mathrm{k} 2+\mathrm{I} \cdot \mathrm{k} 3$

$\mathrm{M}: \mathrm{M}$ 值 $\left[{ }^{\circ} \mathrm{C}\right] \quad \mathrm{T}:$ 気温 $\left[{ }^{\circ} \mathrm{C}\right]$

$\mathrm{H}$ : 絶対湿度 $[\mathrm{g} / \mathrm{kg}(\mathrm{DA})] \quad \mathrm{I}$ : 水平面全天日射量 $\left[\mathrm{MJ} / \mathrm{m}^{2}\right]$ $\mathrm{k} 2:$ 係数 $\left[{ }^{\circ} \mathrm{C} \cdot \mathrm{kg}(\mathrm{DA}) / \mathrm{g}\right] \quad \mathrm{k} 3:$ 係数 $\left[{ }^{\circ} \mathrm{C} \cdot \mathrm{m}^{2} / \mathrm{MJ}\right]$ $\mathrm{k} 2$ は絶対湿度に関する係数で日本全国、年間一定値としている。一方、 k3 は日射量に関する係数で日本全国、日ごとに定めた值としいている。

注 2）暖房デグリ $\mathrm{M}$ 值とは、 $\mathrm{M}$ 值と設定基準温度との差を暖房期間に渡って 積算した值である。

注 3）冷房デグリ $\mathrm{M}$ 值とは、 $\mathrm{M}$ 值と設定基淮温度との差を冷房期間に渡って 積算した值である。

\section{参考文献}

1)財団法人建築環境・省エネルギー機構：住宅の省エネルギー基準の解 説,pp.31-37,2002

2)関口武: 日本の気候区分東京教育大学地理学研究報告 N0.3,pp.65-78,1959 3)建設省：建設省総合技術開発プロジェクト,省エネルギー住宅システムの開 発報告書, 1982

4)松尾陽,赤坂裕, 石野久彌,滝沢博 : 標準年気象データに関する研究,空気調 和・衛生工学,第 48 巻,第 7 号,pp.85-107,1974

5)橋口洋,赤坂裕,二宮秀與,曽我和弘：住宅の暖冷房消費エネルギーに基づく 日本の地域区分 その 1 暖房デグリ $\mathrm{M}$ 值、冷房デグリ $\mathrm{M}$ 值の地域差に基づ く地域区分, 日本建築学会大会学術講演梗概集 D-2,pp.213-214,1996

6)赤坂裕,荒井良延,井川憲男, 石野久彌,永村悦子,永村一雄,郡公子,曽我和弘,西 岡真稔,二宮秀與,松本真一：拡張アメダス気象データ 1981-2000, 日本建築 学会, 2005

7)財団法人建築環境・省エネルギー機構 : 住宅事業建築主の判断基準 ガイド ブック ,2009

8)財団法人建築環境・省エネルギー機構：SMASH for Windows Ver.2 住宅 用熱負荷計算プログラム ユーザーマニュアル,2000

9)小倉義光：一般気象学,東京大学出版会,pp.21-25,1999

10)Google Earth,http://earth.google.co.jp (2012 年 1 月 27 日参照)

（2012年 3 月 9 日原稿受理，2012年 8 月 10 日採用決定） 